\title{
FLOOD RISK MANAGEMENT IN NIGERIA: A REVIEW OF THE CHALLENGES AND OPPORTUNITIES
}

\author{
V.O. OLADOKUN ${ }^{1} \&$ D. PROVERBS ${ }^{2}$ \\ ${ }^{1}$ Department of Industrial and Production Engineering, University of Ibadan, \\ Nigeria and a Commonwealth Academic Fellow, funded by the UK government. \\ ${ }^{2}$ Faculty of Computing, Engineering and the Built Environment, Birmingham City University.
}

\begin{abstract}
Flooding has become a major hazard in Nigeria in recent years due to a growing population, rapid urbanization and extreme weather events. This study provides a critical review and characterisation flood risk management (FRM) practices in Nigeria with a view to highlighting current weaknesses and opportunities, as well as giving recommendations for practice and for further research. Databases of academic literature, covering a wide range of FRM issues, were systematically queried and mined using suitable keywords. A structured review of the resulting literature was carried out and several past flood events and associated responses reviewed as case studies. Absence of integrated FRM systems, lack of inter agency coordination, substandard and weak infrastructures, inadequate drainage network, high urban poverty, low level literacy, cultural barriers and weak institutions characterize current FRM practices. The study recommends the adoption of an integrated approach to urban infrastructural development starting with a review of ongoing and planned infrastructural systems and projects with a view to optimizing their FRM capabilities while still meeting their intended purposes. The empowerment of more entrepreneurs into FRM solutions development and service delivery as well as the inclusion of FRM concepts and practices into the nation's educational curricula was also recommended. Nigeria also needs a multidisciplinary platform for generating effective strategic policies and efficient operational mechanisms for FRM.
\end{abstract}

Keywords blue green, flood, flood risk management, infrastructure, Nigeria, urbanization.

\section{INTRODUCTION}

Flooding has become a major hazard in Nigeria in recent years. It was estimated that Nigeria suffered combined losses of more than $\$ 16.9 \mathrm{~b}$ in damaged properties, oil production, agricultural and other losses due to flood events in 2012 alone [1, 2]. Increased flood events coupled with the lack of coping capacity and high levels of vulnerability of the people have continued to put many lives and properties at risk [3]. Stakeholders are therefore increasingly concerned about the threats of flooding to communal safety and national development. While there have been various interventions in the past, there is a lack of integrated and sustainable Flood Risk Management (FRM) systems and practices in Nigeria [4]; sustainable FRM system reflects the ecological make up, infrastructural development, institutional behaviour and other techno-socio-economic characteristics of its environment $[5,6]$.

Meanwhile, it has been observed that the literature is sparse in many critical areas of flooding and FRM for Nigeria. For instance Egbenta et al. [2] observed that there is a paucity of information on the effects of flood hazard on the values of properties in Nigeria while Nkwunonwo et al. [7] asserted that only journalistic and non-quantitative evidence are available on some 
critical aspects of flooding in Nigeria. A recent review by Komolafe et al. [3] highlighted the absence of the use of state of the art flood models integrating all hydrological processes for accurate prediction and mapping of flooding and its associated risks in Nigeria.

Moreover, while Nigeria is the most populous country and has the largest economy in Africa, case studies on Nigerian flooding are scant or absent in many important global flood studies and documents. For instance in a major World Bank document [8] on guidelines for FRM in developing countries, not a single case study or reference was made to Nigeria. Therefore, it is imperative to have further research in order to have a sound and legitimate basis for effective planning and development of Nigerian FRM policies. Particularly, there is a need to identify FRM approaches and systems adopted elsewhere and how to adapt them for Nigeria. This study aimed to provide a critical review and characterisation of FRM in Nigeria with a view to highlighting current weaknesses and opportunities. This will lead towards the development of conclusions and recommendations for practice and for further research.

\section{ELEMENTS OF THE NIGERIAN FLOOD SYSTEM}

This section highlights some of the socio-economic, techno-environmental, ecological and other factors that characterize flooding and flood hazards in Nigeria and attempts to highlight some elements of current FRM practices.

\subsection{Frequency and regularity of occurrences}

Until recently major flood disasters rarely occur in Nigeria. Recorded cases of flooding in Nigeria date back to 1963 when Ogunpa River flooded Ibadan city causing loss of lives and properties with reoccurrences in 1978, 1980 and 2011 [9, 10]. The 1980 flood, which caused huge loss of lives and properties, brought some notoriety and attention to the disaster potential of the river and immediately provoked a flurry of FRM responses such as the initiation of the Ogunpa channelization project, educative radio and television jingles on FRM practices, relocation of structures and properties from flood plains [11, 12]. However the sense of urgency and priority attached to these FRM projects waned after some years of respite. For instance, the channelization project was abandoned for a long period, radio and television jingles ended, and by the late 90 s, it was clear that city planning authorities had gone back to old habits of allowing structures on floodplains obstructing flood channels [13].

Agbola et al. [10] noted that while the rainfall of August 26, 2011 was not the highest in the recorded history of the city, the monetary value of damages to property that resulted from the event, was by far the most costly. The official estimated losses and damages from the 1980 single flood episode rainfall of $274.0 \mathrm{~mm}$ was put at N300 million ( $\$ 1.9$ million) while that of 2011 rainfall of $187.5 \mathrm{~mm}$ was put at N2.1 billion (\$13.3 million). Some twelve anthropogenic factors were identified to have contributed to the exaggerated level of devastation that trailed the 2011 Ibadan flood [10, 13]. Also the 2011 flood event motivated the Nigerian government to approach the World Bank to finance a long term major FRM project in Ibadan city. While responses to the past flooding events have been piecemeal, mainly focusing on alleviating immediate and short-term needs such as rebuilding of destroyed assets, the Ibadan Urban Flood Management Project (IUFMP) recognizes the imperative of a long term integrated approach to FRM for the city [14]. The project with a closing date of June 2022 and objective of improving the state's capacity to manage flood risk in Ibadan is on course [15]. 
Meanwhile, because the meantime between floods can be irregular and deceptively long, stakeholders tend to forget the lessons of the 'last' flood disaster and become relaxed until another flood strikes. This disruption to both institutional and individual memory coincides with what obtains in the UK where FRM tends to become prominent in the immediate aftermath of a major inundation. Although the awareness of resilience measures among UK residents is high, the level of implementation is low with only $10 \%$ claiming to have implemented a full package of the measures [16]. While FRM in UK is characterized by a robust flood insurance scheme [17] as well as an advanced flood warning system, which compensate for the low level of resilience measures, Nigeria has poor flood warning systems as well as a poor flood insurance scheme $[18,19]$. Hence, building resilience capability to cope with increasing climate variability remains the most viable option for FRM in Nigeria.

\subsection{Nigeria flood prone areas}

With increased and rapid urbanization of Nigeria, the landscape of flood prone communities and assets are on the increase. Some key causes of the increasing vulnerability of Nigerian Urban areas to flooding were summarized by Odufuwa et al. [19] to include inadequate drainage systems and increased replacement of natural and absorptive soil cover with impervious materials such as concrete. The authors also blamed deforestation of hillsides which leads to increase in the quantity and rate of runoff. Figure 1 depicts areas that are exposed to flooding events. The areas and sources of major flooding can be categorised as follows.

1. Coastal cities and settlements: Nigeria has over $853 \mathrm{~km}(530 \mathrm{mi})$ of coastline with extensive low-lying areas, and heavily industrialized areas prone to flooding [1]. Lagos, the main commercial hub of West Africa, Warri and Portharcout, hosting Nigeria's Petroleum infrastructures, are increasingly exposed to ocean flooding.

2. Communities and settlements along the two major Rivers, (Niger and Benue), cutting across the nation (see Fig. 1). Urban and rural communities along the River Niger and its tributaries have been shown to be most affected by flooding [20,21].

2. Communities downstream of dammed rivers and on the banks of other major rivers. For instance, Ilorin, a North central city, has been severely flooded by River Asa that runs through the city [22].

In light of these issues, the following questions need to be answered. How many cities, towns and settlements along these flood prone zones are at risk? What is the population and demographic characteristics of the vulnerable areas? What are the major economic activities and industries along these flood prone areas and what are the risks and implications of a major flooding incident?

\section{CHARACTERISTICS OF FRM SYSTEMS IN NIGERIA}

Some characteristics and factors observed in the Nigerian FRM systems are discussed and benchmarked against recommended practices in the following.

\subsection{Absence of integration between urban development and FRM}

In most of the Nigerian urbanization experience it can be observed that there is a disconnection between FRM systems and other elements of the urbanization process. In addition to the 


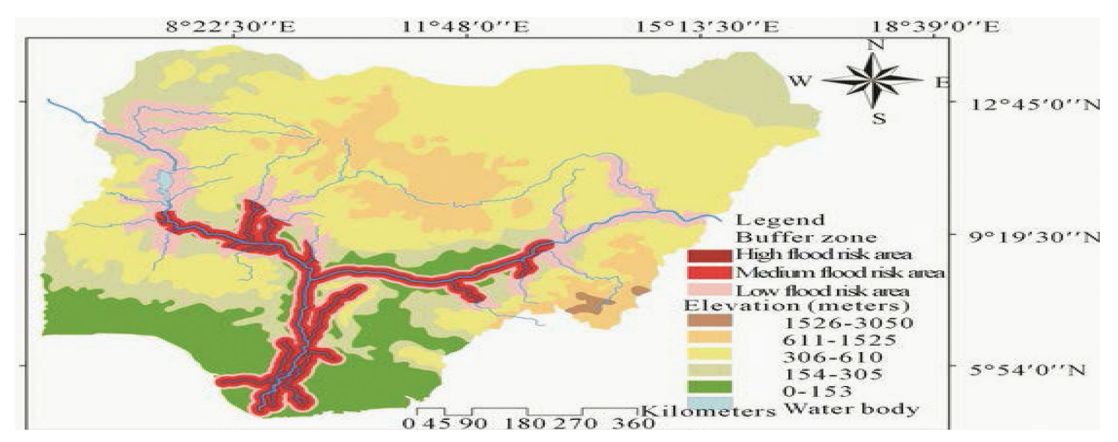

Figure 1 A map of Nigerian Flood plains [21]

technical and financial challenges faced by various government agencies, limited interagency coordination has militated against the success of FRM [23]. Usually, FRM systems are designed without proper integration with other developmental systems such as power infrastructures, water supply systems, transportation networks, recreational facilities and so on. An example is a situation where road construction projects can be executed by a department of public works without adequate consultation with other relevant departments such as that of water resources, environment, or agriculture. There have been several cases where road contractors damage major water pipelines serving as controlled relief outlets to dams. This in turn compromises the flood safety features of such dams and ultimately leads to the flooding of adjoining and downstream areas of the dams. There have been cases where road contractors excavate borrow pits during dry seasons without adequate consideration for flooding. Such projects end up damaging the capacity of the adjoining landscape to withstand erosion by removing the natural defence of the ecosystem against flooding [24].

An integrated and holistic approach to development whereby flood management is a high priority sub-system has been identified as the only sustainable approach to FRM [8, 25]. This approach to development will require a high level of coordination and integration among the various agencies of the Nigerian government. Inter agency coordination and integration, visa-vis FRM, will allow for the interrelations exiting among urbanization processes and systems to be systematically explored and exploited in a complimentary manner. For instance, in solving transportation issues, water channels built for flood control can be designed to also provide water ways to ease transportation in places like Lagos. Solving power supply demands with large numbers of wind turbines installed along the offshore line of Lagos, for instance, will reduce the landing velocity of coastal waves/storms by extracting the kinetic energy of the storms to drive power generators. This may provide a more effective and efficient protection, than the construction of crude concrete embankments and serve to benefit both energy production and FRM concerns.

Ironically, residents of many Nigerian communities ravaged by flooding also lack access to potable water. For instance Adesogan [26] reported poor water supply coverage for nearly $22 \%$ across the South West region of Nigeria while Oke et al. [27] noted there is a challenge of water sourcing within a major portion of this region. An integrated solution may be a rainwater harvesting system designed to meet water supply needs and also serving as an FRM scheme. Rainwater harvesting has been noted to offer some mitigation against extreme runoff events [28, 29]. Economically, Hashemi and Berndtsson [30] reported that floodwater har- 
vesting is an inexpensive method for flood mitigation and artificial recharge of aquifers as it results in a large economic return for relatively small investment.

However, the present low level of inter agency coordination as well as the absence of solution systems integration in the Nigerian urbanization process is a hindrance to such holistic approaches. Apart from the federal government, there are 36 autonomous state governments, over 750 local authorities, hundreds of private organizations, companies, NGOs and individual property owners implementing various FRM solutions without appropriate coordination and collaboration. Often these entities put in place FRM measures that are only sub-optimal for their own immediate regions and may end up causing more damage or induce floods in other locations and regions. There have been reported cases where dams, channels, and structures built to protect a local region, community or private property causes direct runoff water into other communities downstream [31].

\subsection{Focus on structural FRM measures}

In tackling flood risk in Nigeria, the main focus has been on structural measures coupled with over dependence on imported expertise and technologies. The propensity to award contracts to build more structural flood defences, canals, embankments, culverts and bridges without sufficient consideration for less costly and more sustainable, non-structural solutions is evident in the budgets of the nation. Unfortunately, these structures are usually handled by foreign contractors and experts with limited understanding of the local situation resulting in the limited knowledge transfer to indigenous experts [32]. Such structures, which are usually copies of the solutions adopted in some distant countries and different socio-ecological settings without sufficient adaption for the local scenario, create other socio-technical problems. Such projects lack the right mix of soft elements like advocacy, education, stakeholders' participation, and consultation that can engender a sense of project co-production and ownership. For instance, several flood canals and drainages have turned into refuse dumps few years after commissioning [7, 10, 22, 33]).

Experience has shown that these capital intensive concrete structures and civil works rarely offer adequate and sustainable defence against the threats of flood. This coincides with major flooding in the UK and news of the failure of newly built multi-million pound flood defences in many parts of the country. It is becoming apparent that non-structural measures, institutional preparedness and coping capacity of the affected UK communities are more important in the defence against floods. Stakeholders in Nigeria are slowly recognizing the imperative of exploring non-structural FRM measures [13].

\section{FLOODING HAZARD INDUCING FACTORS IN NIGERIA}

There are a number of factors in Nigeria that induce and aggravate the impacts of flooding. Some of these factors are now discussed.

\subsection{Substandard infrastructures induced flooding}

The causal relationships that exist among various elements of the modern built environment system provide a credible platform for understanding the peculiar challenge of FRM in Nigeria. While Nigeria has made considerable investment in infrastructure projects such as road networks, bridges, and other modern facilities for the growing population, the process of planning, designing and constructing such facilities has not reflected any serious system 
thinking. Also due to corruption, mismanagement and incompetence, many of the facilities are substandard and collapse long before their expected life span [34].

For example, when a substandard bridge or road segment collapses during a rainy season, which is a common occurrence in Nigeria, the debris and concrete materials end up blocking or reducing the carrying capacity of the channel. This will eventually cause 'induced' flooding of the adjoining area upstream to the collapsed bridge. Also when a road segment fails due to poor and substandard civil work, commuters will ultimately divert traffic to some alternative routes thereby over stretching these other routes. For instance, heavy truck drivers are compelled to move over low capacity bridges and roads which will in turn cause more bridges to collapse and the chain continues. Invariably, substandard elements in one region of the built environment will remotely increase the risk of flooding of some other regions in the built environment. Unfortunately, in many instances, it can be a complicated process to trace back the original cause, especially if the affected infrastructures fall within different authorities.

The standards and type of materials used for many buildings in Nigeria cannot withstand mild floods. In a study by Abaje et al. [35]), it was observed that about $69 \%$ of the houses in a state in Northern Nigeria were built with unbaked mud and on foundations of loose sandy soil, while Anosike and Oyebade [36]; Ewa and Ukpata [37] reported that sandcrete blocks, used in over $90 \%$ of Nigerian urban houses, are below required standards. Consequently, these houses are highly exposed and vulnerable to flood damage. The activities of unqualified builders and poor culture of regulations' enforcement in the building sector have been blamed for the preponderance of weak structures [38-40]. Meanwhile, poorly built infrastructural systems, such as high voltage power lines, bridges, unprotected construction sites, and uncompleted buildings, readily collapse during flooding thereby aggravating the number of fatalities and injuries.

With the absence of reliable potable water network [26], majority of Nigerian houses depend on shallow wells and streams, mostly located close to faecal pit latrines and sewage soak away pits, for water supply. The water supply system thus has become easily and readily contaminated during flood events leading to further health and water supply issues.

\subsection{Poorly planned and managed urbanization process}

The growth and expansion of urban communities in Nigeria has been known to be poorly managed. Lack of proper spatial planning, poor land use management and absence of good corporate governance characterizes urban development in Nigeria [4, 35, 41]. The suburbs of big cities like Ibadan are notorious for this. Town planning officials in many of these cities have become compromised such that residents, companies, government agencies and NGOs alter the design and use of buildings without proper approvals. Potential flooding inducing alterations like dump sites, borrow pits, trenches, water dredging, and sand filling can occur without properly carried out environmental impact analysis. The use of geotechnical studies and other pre-design studies to ascertain the suitability of an area is uncommon.

This absence of a proper urban development planning process has over the years resulted in the gross distortion of ecological systems and, in the words of Odufuwa et al. [19], abused the flood plains especially in the low lying cities. These damaging distortions to the ecosystems include the replacement of the natural and absorptive soil cover with concrete and the silting up of drainage channels [4]. For instance, deforestation of hillsides, which has the effect of increasing the quantity and rate of runoff, and through soil erosion, may have 
contributed to the increase in the reported incidence of mud and landslides during floods in recent years in Nigeria [42, 43].

\subsection{High prevalence of urban poverty}

Poverty is a major challenge to development in Nigeria $[44,45]$. Demographic data show more than 64\% of the nation's population, of over 160 million, live on less than $\$ 1$ a day [46]. Studies have confirmed that residents, especially women, in the lower income neighbourhoods recorded higher impacts and slower recovery after flooding Ajibade et al. [47]). Increased poverty levels coupled with insecurity in the Northern region in recent times have resulted in increased movement to the low-lying and coastal cities in the South like Lagos. Unfortunately, the high cost of land and housing in these cities means that most internal migrants end up living in 'affordable' slums or turn existing areas into slums. While swampy and low level areas may be cheaper to acquire per plot they are usually very costly to develop. Swamps and waterlogged lands require heavy investments in deep concrete foundations, high volume of sand filling and dredging, networks of drainage and other infrastructures required to minimize the impact of flooding.

The number and resident population of the slum areas in major Nigerian cities have continued to rise [48]. Fragile and inadequate sewage systems become overburdened and collapse, refuse and solid waste management facilities become overstretched to the extent that drainage networks get blocked and flooding becomes inevitable. So poverty is a primary driver of urban flooding, the flooding in turns creates further poverty as uninsured residents lose their properties and livelihoods to flood disasters. Hence, there is a vicious cycle of flooding, poverty and deprivation [48, 49].

Attempts in the past to relocate people from swampy slums have met stiff and violent resistance due to absence of adequate engagement of stakeholders through consultations, advocacy, and education. Such relocations should be seen to be socially equitable with fair compensation. This has not been the case in the past where relocation from flood prone areas has been used as a pretext by the ruling elites to take possession of lands close to the various beaches and water front without fair compensation. A sustainable FRM scheme must embrace social justice [50]. Involuntary resettlement from development projects should be properly managed to avoid long-term hardship and impoverishment of affected persons and communities. Unmitigated impacts often give rise to severe economic and social stress [51].

\subsection{Absence of water drainage network}

Inadequate and poorly maintained drainage networks have been identified as a major contributory factor to the increased frequency of urban flooding in Nigeria [41, 52]. Compared to the UK and other developed nations, Nigerian urban areas lack drainage network for waste and flood water with many depending on rivers and tributary streams flowing through them, this situation was particularly identified for Ilorin by Kolawole et al. [22]. For instance Abaje et $a l$. [35] found that in some Northern part of the country $64.5 \%$ of the residents have no access to drainage systems.

\subsection{Cultural resistance to change}

Ignorance due to low level literacy, superstitious beliefs such as rivers regarded as deities to be appeased when they overflow their banks are common among many Nigerian tribes. In 
many cities, drainage systems have been blocked with refuse by residents who dump wastes in drainages [35].

\section{OPPORTUNITIES FOR SUCCESSFUL AND SUSTAINABLE FRM SOLUTIONS}

Some techno-socio-economic and geo-political factors prevailing in Nigeria offers some unique opportunities that support adoption of sustainable integrated FRM systems. These factors are identified and characterized in the following.

\subsection{Emerging infrastructures}

With relatively little investment in modern urban infrastructure, Nigeria has the opportunity to urbanize with Blue-Green (BG) systems. Nigeria does not face the constraint of space, which escalates the cost of retrofitting of BG infrastructures into urbanized catchments, like many developed countries [53]. Blue systems include ponds, flowing waterways, wet detention basins and wetlands existing within the drainage network. Green infrastructures refers to natural land and plant based ecological treatment systems and processes made up of assets such as open spaces, parks, recreation grounds, woodlands, gardens, green corridors etc [53]. BG FRM revolves around the concept of 'living with water', developing resilience to flooding and making space for water through BG infrastructures [54].

\subsection{Stable geological zone}

Nigeria is located in an environment not prone to serious natural hazards such as earthquakes, landslides, tsunamis, hurricanes, volcanic eruptions [2]. Relative to other parts of the globe, destructive geological events in Nigeria are rare and mild. Dealing with floods without the aggravated effects of these factors makes planning less complicated and allows for effective modelling.

\subsection{Young population and huge land area}

Relocation of residents from a flood prone area will usually be more complicated for older populations with some deep rooted attachments to 'their' communities and properties. It is usually traumatic for older people to part with their homes or be relocated involuntarily after a flood event [55]. However, with a demographic distribution dominated by young people with weak economic ties, implementing relocation programs with appropriate incentives may face less resistance in Nigeria. Moreover, given the infant state of Nigeria's infrastructural development and the nation's relatively huge land expanse outside flood plains the economic cost of relocation programs will be greatly moderated.

\section{CONCLUSIONS}

This study reviewed flooding and FRM in Nigeria. Some characteristics and challenges were discussed. It was noted that while the increased incidence of floods in recent times has increased levels of awareness and raised the tempo of FRM activities in Nigeria, there is a general lack of coordination and integration across several important FRM systems and processes. FRM approaches and responses have been generally geared toward sub-sector or sub-regional optimization. There is an absence of holistic or system thinking in urban system planning and development. There is a disconnection between FRM systems and other subsystems of the built environment, resulting, inadvertently, in inefficient and ineffective FRM systems. While enor- 
mous resources and investment have been put into a number of structural FRM measures, there has been a limited adaptation of these technologies to the Nigerian socio-technical environment as well the absence of the required knowledge transfer to Nigerian experts.

\subsection{Recommendations}

Meanwhile, there are several socio cultural features, characteristics as well as techno-economic and development opportunities which support the adoption of sustainable, integrated FRM systems in Nigeria and also favor the pursuit of Blue-Green infrastructural development approaches at relatively lower cost. These potentials can be optimally exploited if there is a framework for understanding the interactions of the urban development process and FRM system in Nigeria. The following recommendations for practice and for further research are therefore considered useful.

\subsubsection{Practice and policies}

1. Adoption of an integrated approach to urban infrastructural development.

2. A review of ongoing and planned infrastructural projects with a view to optimizing their FRM capabilities while still meeting their intended purposes.

3. Establishment of centre of excellence in Flood Risk Research and Capacity Development to serve as a multidisciplinary platform for generating effective strategic policies and efficient operational mechanisms for FRM in Nigeria.

4. Adoption of pragmatic steps toward developing and including suitable FRM concepts and practices into the nation's educational curricula.

5. Mobilizing and empowering more entrepreneurs into FRM solutions development and service delivery in Nigeria.

\subsubsection{Further research}

1. Performance evaluation of past and ongoing FRM interventions in Nigeria. This requires development of FRM performance evaluation models.

2. Development of techno-economic evaluation framework to optimize the adoption of BG technologies such as rainwater/floodwater harvesting, pumped hydro power systems, and transport canals for FRM measures.

3. Development of low cost and easy to use flood risk assessment tools at both individual property and community levels.

3. FRM knowledge/skills gap analysis across various relevant professions with a view to identifying human capacity requirements for sustainable FRM.

\section{REFERENCES}

[1] Amangabra, G.T. \& Obenade, M., Flood vulnerability assessment of Niger Delta states relative to 2012 flood disaster in Nigeria. American Journal of Environmental Protection, 3(3), pp. 76-83, 2015.

[2] Egbenta, I.R., Udo, G.O. \& Otegbulu, A.C., Using hedonic price model to estaimate effects of flood on real property value in Lokoja Nigeria. Ethiopian Journal of Environmental Studies and Management, 8(5), pp. 507-516, 2015.

http://dx.doi.org/10.4314/ejesm.v8i5.4 
[3] Komolafe, A.A., Adegboyega, S.A. \& Akinluyi, F.O., A review of flood risk analysis in Nigeria. American Journal of Environmental Sciences, 11(3), pp. 157-166, 2015. http://dx.doi.org/10.3844/ajessp.2015.157.166

[4] Adedeji, O.H., Odufuwa, B.O. \& Adebayo, O.H., Building capabilities for flood disaster and hazard preparedness and risk reduction in Nigeria: need for spatial planning and management. Journal of Sustainnable Development in Africa, 14(1), pp. 45-58, 2012.

[5] Storbjörk, S., Governing climate adaptation in the local arena: challenges of risk management and planning in Sweden. Local Environmen: The International Journal of Justice and Sustainability, 12(5), pp. 457-469, 2007. http://dx.doi.org/10.1080/13549830701656960

[6] Tran, P., Shaw, R., Chantry, G. \& Norton, J., GIS and local knowledge in disaster management: a case study of flood risk mapping in Vietnam. Disasters, 33(1), pp. 152-169, 2009. http://dx.doi.org/10.1111/j.1467-7717.2008.01067.x

[7] Nkwunonwo, U.C., Whitworth, M. \& Baily, B., Review article: a review \& critical analysis of the efforts towards urban flood reduction in the Lagos region of Nigeria. Natural Hazards and Earth System Science Discussion, 3, pp. 3897-3923, 2015. http://dx.doi.org/10.5194/nhessd-3-3897-2015

[8] Jha, A.K., Bloch, R. \& Lamond, J., Cities and Flooding: A Guide to Integrated Urban FRM in the 21st Centuries, World bank, DC, 2012. http://dx.doi.org/10.1596/978-0-8213-8866-2

[9] Adegbola, A.A. \& Jolayemi, J.K., Historical rainfall-runoff modeling of river Ogunpa, Ibadan, Nigeria. Indian Journal of Science and Technology, 5, pp. 2725-2728, 2012.

[10] Agbola, B., Ajayi, O., Taiwo, O. \& Wahab, B., The august 2011 flood in Ibadan, Nigeria: Anthropogenic causes and consequences. International Journal of Disaster Risk Science, 5, pp. 207-217, 2012. http://dx.doi.org/10.1007/s13753-012-0021-3

[11] Sangodoyin, A.Y. \& Essein, O.E., Effect of urbanization, waste disposal and hydrological factors on flooding of Ogunpa stream in Nigeria. Discovery and Innovation, 8(1), pp. 11-19, 1996.

[12] Egunjobi, L., Human elements in urban planning and development: Ibadan. Habitat International, 10(4), pp. 147-153, 1986. http://dx.doi.org/10.1016/0197-3975(86)90079-2

[13] Ajayi, O., Agbola, S.B., Olokesusi, B.F., Wahab, B., Taiwo, O.J., Gbadegesin, M., Taiwo, D.O., Kolawole, O., Muili, A., Adeola, M.A., Olutade, O.G., Shiji, F. \& Abiola, N.A., Flood management in an urban setting: a case study of ibadan metropolis. Special Publication of the Nigerian Association of Hydrological Sciences, pp. 65-81, 2012.

[14] Word Bank, Ibadan Urban Flood Management Project: Project Appraisal Document, World Bank, 2014.

[15] Salim, R., Nigeria - Ibadan Urban Flood Management Project : P130840 - Implementation Status Results Report: Sequence 03. World Bank, 2015.

[16] Joseph, R., Proverbs, D. \& Lamond, J., Resilient reinstatement: What can we learn from the 2007 flooding in England? Flood Recovery, Innovation and Response IV, 184, pp. 175-186, 2014.

[17] Cameron, D. \& Proverbs, D., Improving the uptake of flood risk adaptation measures for domestic properties in an insurance regime under transition. Flood Recovery, Innovation and Response IV, 184, pp. 139-149, 2014. 
[18] Adelekan, I.O., Vulnerability assessment of an urban flood in Nigeria: Abeokuta flood 2007. Natural Hazards, 56(1), pp. 215-231, 2011.

http://dx.doi.org/10.1007/s11069-010-9564-z

[19] Odufuwa, B.O., Adedeji, O.H., Oladesu, J.O. \& Bongwa, A., Floods of fury in Nigerian cities. Journal of Sustainable Development, 5(7), pp. 69-79, 2012.

[20] Amadi, L. \& Ogonor, C.U.M., Climate change, environmental security and displacement in Nigeria: experience from niger delta flood disaster, 2012. African Journal of Environment Science and Technology, 9(1), pp. 53-64, 2015. http://dx.doi.org/10.5897/AJEST2014.1749

[21] Nkeki, F.N., Henah, P.J. \& Ojeh, V.N., Geospatial techniques for the assessment and analysis of flood risk along the Niger-Benue basin in Nigeria. Journal of Geographic Information System, 5, pp. 123-135, 2013. http://dx.doi.org/10.4236/jgis.2013.52013

[22] Kolawole, O.M., Olayemi, A.B. \& Ajayi, K.T., Managing flood in Nigerian cities: risk analysis and adaptation options - Ilorin city as a case study. Archives of Applied Science Research, 3(1), pp. 17-24, 2011.

[23] World Bank, Ibadan Urban Flood Management Project: Environmental and Social Management. Framework Final Report. Oyo state Government of Nigeria, 2014.

[24] Nwachukwu, M.A. \& Eburukevwe, O., Assessment of environmental hazards: Linking borrow pits, gully erosion, and road failure. Journal of Civil Engineering and Construction Technology, 4(6), pp. 199-210, 2013.

[25] Baker, R., Blue space thinking. In Flood Hazards: Impacts \& Responses for the Built Environment, eds. J. Lamond, C. Booth, F. Hammond \& D. Proverbs, Taylor \& Francis: New York, pp. 191-205, 2012.

[26] Adesogan, S.O., Strategies and techniques of providing adequate and affordable potable water in rural areas of Nigeria. International Journal of Water Resources and Environment Engineering, 6(1), pp. 32-39, 2014. http://dx.doi.org/10.5897/IJWREE2013.0418

[27] Oke, M.O., Martins, O. \& Idowu, O.A., Determination of rainfall-recharge relationship in River Ona basin using soil moisture balance \& water fluctuation methods. International Journal of Water Resource and Environment Engineering, 6(1), pp. 1-11, 2014. http://dx.doi.org/10.5897/IJWREE2013.0443

[28] Huang, C., Hsu, N., Wei, C. \& Luo, W., Optimal spatial design of capacity and quantity of rainwater harvesting systems for urban flood mitigation. Water, 7, pp. 5173-5202, 2015. http://dx.doi.org/10.3390/w7095173

[29] Magaliano, P.N., Murray, F., Baldi, G., Aurand, S., Paez, R.A., Harder, W. \& Jobabagy, E.G., Rainwater harvesting in dry Chaco: regional distribution and loca balance. Journal of Arid Environments, 123, pp. 93-102, 2015. http://dx.doi.org/10.1016/j.jaridenv.2015.03.012

[30] Hashemi, H. \& Berndtsson, R., Water resources management through rainwater harvesting in arid area. In 7th IWA International Conference on Efficient Use and Management of Water, Paris, 2013.

[31] Alayande, W.A., Mohammed, G., Caleb, I. \& Deimode, M.I., Assessment of urban flood disaster: a case study of 2011 Ibadan floods. Hydrology for Disaster Management: Special Publication of the Nigerian Association of Hydrological Sciences, pp. 13-23, 2012. 
[32] Ugochukwu, S.C. \& Onyekwena, T., Participation of indigenous contractors in Nigerian public sector construction projects and their challenges in managing working capital. International Journal of Civil Engineering, Construction and Estate Management, 1(1), pp. 1-21, 2014.

[33] Adewole, I.F., Agbola, S.B. \& Kasim, O.F., Building resilience to climate change impacts after the 2011 flood disaster at the University of Ibadan, Nigeria. Environment and Urbanization, 27(1), pp. 199-216, 2014. http://dx.doi.org/10.1177/0956247814547679

[34] Lanrewaju, A.F., Urbanization, housing quality and environmental degeneration in Nigeria. Journal of Geography and Regional Planning, 5(16), pp. 422-429, 2012. http://dx.doi.org/10.5897/JGRP12.060

[35] Abaje, I.B., Ogoh, A.O., Amos, B.B. \& Abashiya, M., Climate change, flood disaster assessment and human security in Katsina State, Nigeria. American Journal of Human Ecology, 4(4), pp. 47-56, 2015.

[36] Anosike, M.N. \& Oyebade, A.A., Sandcrete blocks and quality management in Nigeria building industry. Journal of Engineering, Project, and Production Management, 2(1), pp. 37-46, 2012.

[37] Ewa, D.E. \& Ukpata, J.O., Investigation of the compressive strengths of commercial sandcrete blocks in calabar Nigeria. International Journal of Engineering and Technology, 3(4), pp. 447-482, 2013.

[38] Fagbenle, O.I. \& Oluwunmi, A.O., Building failure \&collapse in Nigeria: the influence of the informal sector. Journal of Sustainable Development, 3(4), pp. 268-276, 2010.

[39] Mbamali, I. \& Okotie, A.J., An assessment of the threats and opportunities of globalization on building practice in Nigeria. American International Journal of Contemporary Research, 2(4), pp. 143-150, 2012.

[40] Ayedun, C.A., Durodola, O.D. \& Akinjare, O.A., An empirical ascertainment of the causes of building failure and collapse in Nigeria. Mediterranean Journal of Social Sciences, 3(1), pp. 313-322, 2011.

[41] Dalil, M., Mohammad, N.H., Yamman, U.M., Husaini, A. \& Mohammed, S.L., An assessment of flood vulnerabilty on physical development along drainage channels in Minna, Niger State, Nigeria. African Journal of Environment Science and Technology, 9(1), pp. 38-46, 2015. http://dx.doi.org/10.5897/AJEST2014.1815

[42] Inyang, M.P., The role of landslide education in preventing environmental hazards and promoting health in Niger Delta region of Nigeria. International Journal of Science, Environment and Technology, 3(2), pp. 427-433, 2014.

[43] Ezeji, J.I., Reducing risks of contamination breaching the drinking water system through catchment sensitive farming in eastern Nigeria. Pollution Effects and Control, 3(3), p. 148, 2015. http://dx.doi.org/10.4172/2375-4397.1000148

[44] Lame, S.M. \& Yusoff, W.F.W., Poverty reduction in Nigeria: the role of entrepreneurship education. Journal of Educational and Literature, 3(2), pp. 63-71, 2015.

[45] Ike, P.C. \& Uzokwe, U.N., Estimation of poverty among rural farming households in Delta State. Journal of Poverty, Investment and Development, 11, pp. 86-93, 2015.

[46] Joshua, I.A., Makama, J.G., Joshua, W.I., Audu, O. \& Nmadu, A.G., Disasters in Nigeria: a public health perspective. Journal of Community Medicine and Primary Health Care, 26(1), pp. 59-75, 2014. 
[47] Ajibade, I., McBean, G. \& Bezner-Kerr, R., Urban flooding in Lagos, Nigeria parterns of vulnerability \& resilence among women. Global Environment Change, 23(6), pp. 1714-1725, 2013. http://dx.doi.org/10.1016/j.gloenvcha.2013.08.009

[48] Adelekan, I.O., Vulnerability of poor urban coastal communities to flooding in Lagos,Nigeria. Environment and Urbanization, 22(2), pp. 433-450, 2010. http://dx.doi.org/10.1177/0956247810380141

[49] Douglas, I., Alam, K., Mahgenda, M., Mcdonnell, Y., Mclean, L. \& Campbell, J., Unjust waters: climate change,flooding and the urban poor in Africa. Environment and Urbanization, 20(1), pp. 187-205, 2008. http://dx.doi.org/10.1177/0956247808089156

[50] Johnson, C., Penning-Rowsell, E. \& Parker, D., Natural and imposed injustices: the challenges in implementing 'fair' flood risk management policy in England. The Geographical Journal, 173(4), pp. 374-390, 2007. http://dx.doi.org/10.1111/j.1475-4959.2007.00256.x

[51] World Bank, Resettlement Policy Framework; Nigeria, World Bank, 2013.

[52] Ocheri, M. \& Okele, E., Social impact and people's perception of flooding in Makurdi town, Nigeria. Hydrology for Disaster Management, pp. 97-105, 2012.

[53] Lawson, E., Thorne, C., Ahilan, S., Allen, D., Arthur, S., Everett, G., Fenner, R., Glenis, V., Guan, D., Hoang, L., Kilsby, C., Lamond, J., Mant, J., Maskrey, S., Mount, N., Sleigh, A., Smith, L. \& Wright, N., Delivering and evaluating the multiple flood rik benefits in BG cities:an interdiscplinary approach. Flood Recovery, Innovation and Response IV, pp. 113-124, 2014.

[54] Everett, G. \& Lamond, J., A conceptual framework for understanding behaviours and attitudes around 'Blue-Green' approaches to FRM. Flood Recovery, Innovation and Response IV, pp. 101-112, 2014.

[55] Whitlte, R. \& Medd, W., Living with flood: Understanding residents' experiences of recovery. Flood Hazards: Imapacts and Responses for the Built Environment, pp. 281290, 2012. 